\title{
Membrane proteomic analysis of pancreatic cancer cells
}

Xiaojun Liu', Min Zhang ${ }^{1}$, Vay Liang W Go², Shen $\mathrm{Hu}^{1,3^{*}}$

\begin{abstract}
Background: Pancreatic cancer is one of the most aggressive human tumors due to its high potential of local invasion and metastasis. The aim of this study was to characterize the membrane proteomes of pancreatic ductal adenocarcinoma (PDAC) cells of primary and metastatic origins, and to identify potential target proteins related to metastasis of pancreatic cancer.

Methods: Membrane/membrane-associated proteins were isolated from AsPC-1 and BxPC-3 cells and identified with a proteomic approach based on SDS-PAGE, in-gel tryptic digestion and liquid chromatography with tandem mass spectrometry (LC-MS/MS). X! Tandem was used for database searching against the SwissProt human protein database.

Results: We identified 221 \& 208 proteins from AsPC-1 and BxPC-3 cells, respectively, most of which are membrane or membrane-associated proteins. A hundred and nine proteins were found in both cell lines while the others were present in either AsPC-1 or BxPC-3 cells. Differentially expressed proteins between two cell lines include modulators of cell adhesion, cell motility or tumor invasion as well as metabolic enzymes involved in glycolysis, tricarboxylic acid cycle, or nucleotide/lipid metabolism.

Conclusion: Membrane proteomes of AsPC-1 (metastatic) and BxPC-3 (primary) cells are remarkably different. The differentially expressed membrane proteins may serve as potential targets for diagnostic and therapeutic interventions.
\end{abstract}

\section{Introduction}

Pancreatic cancer is one of the most aggressive human malignancies. Despite the advances in therapeutic strategies including surgical techniques as well as local and systemic adjuvant therapies, the overall survival in patients with pancreatic cancer remains dismal and has not improved substantially over the past 30 years. Median survival from diagnosis is typically around 3 to 6 months, and the 5-year survival rate is less than 5\%. As a result, in 2003, pancreatic cancer surpassed prostate cancer as the $4^{\text {th }}$ leading cause of cancer-related death in the US [1]. The main reason for the failure of current conventional therapy to cure pancreatic cancer and the major cause for cancer-related mortality in general, is the ability of malignant cells to detach from the primary tumor site and to develop metastasis in

\footnotetext{
* Correspondence: shenhu@ucla.edu

'UCLA School of Dentistry \& Dental Research Institute, Los Angeles, CA, 90095, USA

Full list of author information is available at the end of the article
}

different regions of the same organ and in distant organs [2,3]. Pancreatic cancer usually causes no symptoms early on, leading to locally advanced or metastatic disease at time of diagnosis [4]. In this regard, it is important to identify the functional proteins that regulate/promote metastasis in pancreatic cancer. This would facilitate the development of strategies for therapeutic interventions and improved management of cancer patients.

The purpose of this study is to compare the membrane proteins expressed in pancreatic cancer cells of primary and metastatic origins using a proteomics approach. Membrane proteomics can be defined as analysis and characterization of entire complement of membrane proteins present in a cell under a specific biological condition $[5,6]$. In fact, membrane proteins account for more than twothirds of currently known drug targets. Defining membrane proteomes is therefore important for finding potential drug targets. Membrane proteomics can also serve as a promising approach to human cancer biomarker
Ciomed Central

() 2010 Liu et al; licensee BioMed Central Ltd. This is an Open Access article distributed under the terms of the Creative Commons Attribution License (http://creativecommons.org/licenses/by/2.0), which permits unrestricted use, distribution, and reproduction in any medium, provided the original work is properly cited. 
discovery because membrane proteins are known to have implication in cell proliferation, cell adhesion, cell motility and tumor cell invasion [7-9].

\section{Materials and methods Cell culture}

AsPC-1 and BxPC-3 cell lines were obtained from American Tissue Culture Collection (ATCC, Rockville, MD). These cell lines were initially generated from patients with pancreatic ductal adenocarcinoma (PDAC) [10-12]. The cells were maintained at $5 \% \mathrm{CO}_{2}-95 \%$ air, $37^{\circ} \mathrm{C}$, and with RPMI 1640 (ATCC) containing 10\% FBS, $100 \mu \mathrm{g} / \mathrm{ml}$ penicillin $\mathrm{G}$ and $100 \mathrm{mg} / \mathrm{ml}$ streptomycin. When the confluence reached $80-90 \%$, the cells were harvested and washed with PBS for three times.

\section{Sample preparation}

Membrane proteins from AsPC- 1 and BxPC-3 cells were isolated with the ProteoExtract Native Membrane Protein Extraction Kit (EMD Chemicals, Gibbstown, NJ). In brief, the cell pellet was washed three times with the Washing Buffer, and then incubated with ice-cold Extract Buffer $\mid$ at $4^{\circ} \mathrm{C}$ for 10 min under gentle agitation. After the pellet was centrifuged at $16,000 \mathrm{~g}$ for $15 \mathrm{~min}$ $\left(4^{\circ} \mathrm{C}\right)$, the supernatant was discarded and $1 \mathrm{~mL}$ ice-cold Extract Buffer|| was added to the pellet. This membrane protein extraction step was allowed for $30 \mathrm{~min}$ at $4^{\circ} \mathrm{C}$ under gentle agitation. Then the supernatant was collected after centrifugation at $16,000 \mathrm{~g}$ for $15 \mathrm{~min} 4^{\circ} \mathrm{C}$.

\section{SDS-PAGE and proteolytic cleavage}

Total membrane protein concentration was measured with the 2-D Quant Kit (GE Healthcare, Piscataway, NJ). In total, $20 \mu \mathrm{g}$ of membrane proteins from each cell line were loaded into a 4-12\% NuPAGE Bis-Tris gel (Invitrogen, Carlsbad, CA) for SDS-PAGE separation. The gel was stained with the Simply Blue staining solution (Invitrogen) to visualize the proteins. Each gel was then cut into 15 sections evenly and proteolytic cleavage of proteins in each section was performed with enzyme-grade trypsin (Promega, Madison, WI) as previously described.

\section{Tandem MS and database searching}

Liquid chromatography (LC) with tandem MS (LC/MS/ MS) of peptides was performed using a NanoLC system (Eksigent Technologies, Dublin, CA) and a LTQ mass spectrometer (Thermo Fisher, Waltham, MA). Aliquots $(5 \mu \mathrm{L})$ of the peptide digest derived from each gel slice were injected using an autosampler at a flow rate of 3.5 $\mu \mathrm{L} / \mathrm{min}$. The peptides were concentrated and desalted on a $\mathrm{C}_{18}$ IntegraFrit Nano-Precolumn (New Objective, Woburn, MA) for $10 \mathrm{~min}$, then eluted and resolved using a $\mathrm{C}_{18}$ reversed-phase capillary column (New Objective). LC separation was performed at $400 \mathrm{~nL} / \mathrm{min}$ with the following mobile phases: A, 5\% acetonitrile/ $0.1 \%$ formic acid (v/v); B, 95\% acetonitrile/0.1\% formic acid (v/v). The chosen LC gradient was: from $5 \%$ to $15 \%$ $\mathrm{B}$ in $1 \mathrm{~min}$, from $15 \%$ to $100 \% \mathrm{~B}$ in $40 \mathrm{~min}$, and then maintained at $100 \% \mathrm{~B}$ for $15 \mathrm{~min}$.

Database searches were performed using the X! Tandem search engine against the SwissProt protein sequence database. The search criteria were set with a mass accuracy of $0.4 \mathrm{Da}$ and semi-style cleavage by trypsin. Proteins with two unique peptides are considered as positively identified.

\section{Western blot analysis}

AsPC-1 and BxPC-3 cells were lysed with a lysis buffer containing $8 \mathrm{M}$ urea, $2 \mathrm{M}$ Thiourea and 4\% CHAPS. Cell lysates with a total protein amount of $40 \mu \mathrm{g}$ were separated with $8-12 \%$ NuPAGE gels at $100 \mathrm{~V}$ for about 2 hours and then transferred to polyvinylidene difluoride membrane using an iBlot system (Invitrogen, Carlsbad, CA, USA). After saturating with $2 \%$ slim milk, the blots were sequentially incubated with primary antibody (1:100 dilution) and horseradish peroxidase-conjugated antimouse IgG secondary antibody (1:1000 dilution, Applied Biological Materials Inc, Richmond, Canada). Anti-annexin A1 was obtained from Abcam (Cambridge, MA, USA) whereas anti-phosphoglycerate kinase 1 was obtained from Santa Cruz Biotechnology (Santa Cruz, CA, USA). Finally, the bands were visualized by enhanced chemiluminescence detection (Applied Biological Materials).

\section{Results}

The purpose of this study was to demonstrate a membrane proteomic analysis of PDAC cells and to identify differentially expressed membrane proteins between primary and metastatic PDAC cells, which may have a potential role in metastasis of pancreatic cancer. Two PDAC cell lines, AsPC- 1 and BxPC-3, were used in this study. AsPC-1 is a cell line of metastatic origin from a 62 year-old female Caucasian whereas BxPC-3 is a cell line of primary PDAC from a 61 year-old female Caucasian [10-12]. Membrane proteins of AsPC-1 and BxPC-3 cells were isolated and then resolved with SDS-PAGE (Figure 1A). Proteins in each gel slices were proteolytically cleaved and the resulting peptides were analyzed with LC-MS/MS. In total, we identified 221 and 208 membrane or membrane-associated proteins from AsPC-1 and BxPC-3 cells, respectively, based on at least 2 unique peptides. A hundred and nine proteins were present in both cell lines but others were only found in AsPC-1 or in BxPC-3 cells (Figure 1B). All the identified proteins and matched peptides from the two cell lines are summarized in Additional file 1, Tables S1 and S2. Proteins with single matched peptide were not tabulated although previous publications reported identification of 


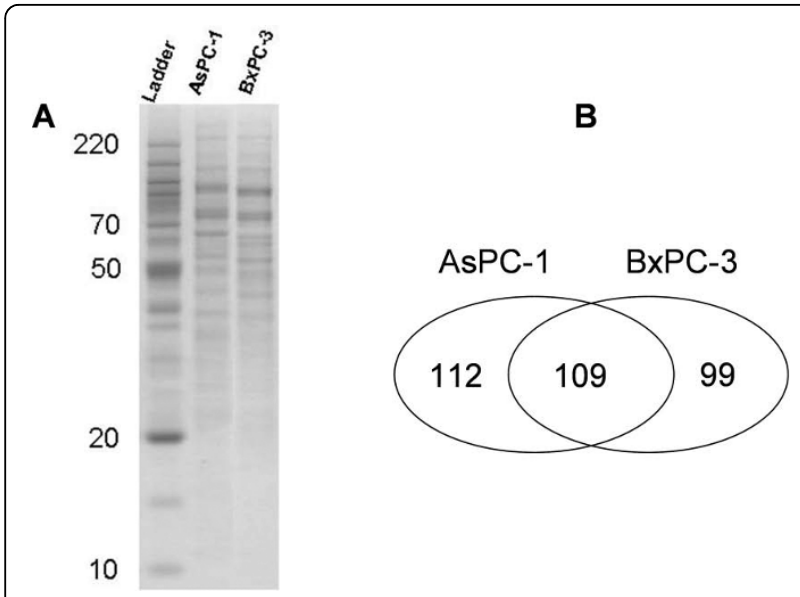

Figure 1 Analysis and identification of membrane proteins in AsPC-1 and BxPC-3 cells using a proteomics approach based on SDS-PAGE, in-gel digestion and LC-MS/MS. (A) Membrane

proteins were isolated, separated with SDS-PAGE and detected with Simply Blue stain. The gel bands were then excised and digested with trypsin, and the resulting peptides were extracted for LC-MS/MS analysis. (B) 221 and 208 proteins were identified from AsPC-1 and BxPC-3 cells, respectively, with 109 proteins present in both cell lines.

membrane proteins based on single unique peptide $[13,14]$. The identified proteins were then sorted according to the Gene Ontology Annotation database (Figure 2). A hundred and four proteins were assigned as membrane proteins in AsPC-1 cells whereas 101 proteins were assigned as membrane proteins in BxPC-3 cells. Table 1 lists the "integral to membrane" proteins found in AsPC-1 and BxPC-3 cells. Besides the membrane proteins, the proteomic analysis also identified many membrane-associated proteins, e.g., extracellular matrix (ECM) proteins. To confirm the proteomic finding, we verified the differential levels of Annexin A1 and PGK1 between AsPC-1 and BxPC-3 cells using Western blotting (Figure 3). Annexin A1 was found to be overexpressed in BxPC-3 cells whereas phosphoglycerate kinase 1 was over-expressed in AsPC-1 cells, which agrees to the results obtained by the proteomic approach.

\section{Discussion}

Metastasis is a highly organ-specific process, which requires multiple steps and interactions between tumor cells and the host. These include detachment of tumor cells from the primary tumor, intravasation into lymph and blood vessels, survival in the circulation, extravasation into target organs, and subsequent proliferation and induction of angiogenesis. Many proteins are critically involved in this process, such as cell-cell adhesion molecules (CAMs), members of the cadherins and, integrins, metalloproteinases (MMPs) and the urokinase plasminogen activator/urokinase plasminogen activator receptor
(uPA/uPAR) system. As modulators of metastatic growth, these molecules can affect the local ECM, stimulate cell migration, and promote cell proliferation and tumor cell survivals [15]. Furthermore, hypoxia can drive genomic instability and lead to a more aggressive tumor phenotype [16,17], which may partially explain the highly metastatic nature of PDAC [18]. Last but not least, angiogenesis plays a critical role in invasion and metastasis in terms of tumor cell dissemination. Based on these new insights in mechanism of tumor invasion and metastasis, novel therapies are currently investigated for therapy of patients with pancreatic cancer [19-21]. Nevertheless, proteomic analysis of primary and metastatic PDAC is required to reveal additional functional proteins that regulate or promote tumor metastasis, as detailed in previous studies [22-24]. These signature molecules are predictors of metastatic risk and also provide a basis for the development of anti-metastatic therapy.

Our proteomic analysis has revealed a large number of differentially expressed membrane/surface proteins between metastatic and primary PDAC cells, and the validity of such a proteomic approach has been verified by Western blot analysis. In fact, the differential expression of membrane proteins between AsPC-1 and BxPC3 can be observed from the SDS-PAGE patterns of membrane proteins from the two cell lines (Figure 1). The proteins showing differential levels include cadherins, catenin, integrins, galectins, annexins, collagens and many others, which are known to have roles in tumor cell adhesion or motility. Cadherins are a class of type- 1 transmembrane proteins that depend on calcium ions to function. They play important roles in cell adhesion, ensuring that cells are bound together within tissues. Catenins, which are proteins found in complexes with cadherins, also mediate cell adhesion. Our study identified cadherins (protocadherin-16 and protocadherin alpha-12) and alpha-2 catenin in primary tumor cells (BxPC-3) but not in metastatic tumor cells (AsPC-1), suggesting a defect in cell-to-cell adhesion in metastatic AcPC-1 cells.

Integrins are members of a glycoprotein family that form heterodimeric receptors for ECM molecules. These proteins are involved in an adhesive function, and they provide traction for movement in cell motility [25]. In total, there are $18 \alpha$-subunits and $8 \beta$-subunits, which are paired to form 24 different integrins through noncovalent bonding. Among these proteins, integrin- $\beta_{1}, \alpha_{2}$, $\alpha_{5}$, and $\alpha_{6}$ represent major adhesion molecules for the adhesion of pancreatic cancer cells to ECM proteins [26]. In our study, integrin- $\beta_{1}$ and integrin- $\beta_{4}$ was found in both tumor cell lines while integrin $\alpha_{2}$ and $\alpha_{5}$ only identified in BxPC-3 cells. Collagens are major ECM proteins. Cell surface-expressed portion of collagens 


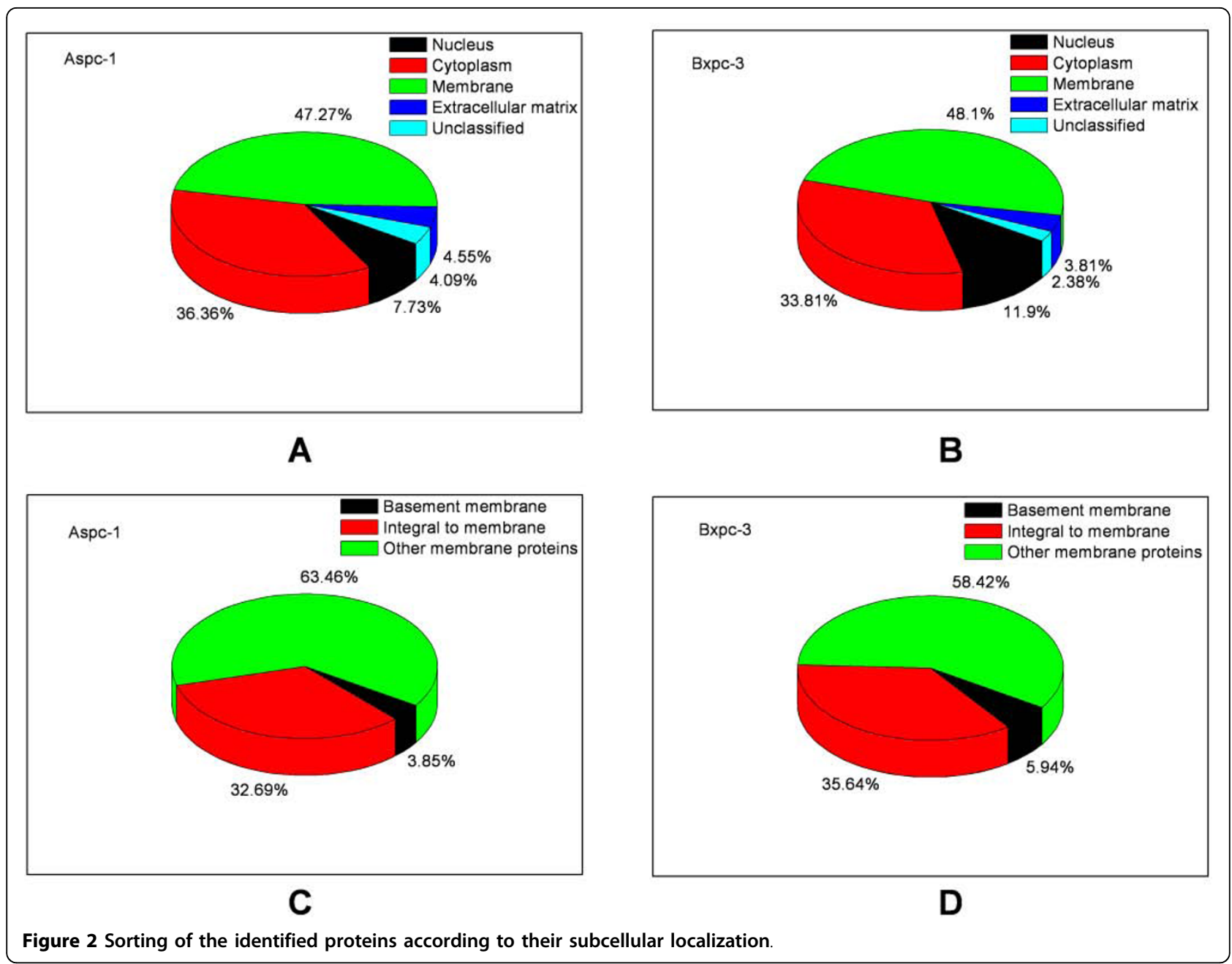

may serve as ligands for integrins, mediating cell-to-cell adhesion. Twelve members of collagen family were found in the BxPC-3 cells whereas only four members found in AsPC-1 cells.

Conversely, galectin-3 and galectin- 4 were found in AsPC-1 but not in BxPC-3 cells. Galectins are carbohydrate-binding proteins and have an extremely high affinity for galactosides on cell surface and extracellular glycoproteins. Galectins, especially galectin-3, are modulators of cancer cell adhesion and invasiveness. Galectin-3 usually exists in cytoplasm, but can be secreted and bound on the cell surface by a variety of glycoconjugate ligands. Once localized to the cell surface, galectin-3 is capable of oligomerization, and the resultant cross-linking of surface glycoproteins into multimolecular complexes on the endothelial cell surface is reported to mediate the adhesion of tumor cells to the vascular endothelium [27]. Lysosome-associated membrane glycoprotein 1 (LAMP1) is a receptor for galectin-3, and was found on the cell surface of highly metastatic tumor cells [28]. Our study revealed LAMP1 in AsPC-1 cells but not in BxPC-3 cells. The cell surface-expressed portion of LAMP1 maybe serve as a ligand for galectin 3, mediating cell-cell adhesion and indirectly tumor spread. FKBP12-rapamycin complexassociated protein (a.k.a., mTOR) was also identified in AsPC- 1 cells but not in BxPC- 3 cells. mTOR is a downstream serine/threonine protein kinase of the phosphatidylinositol 3-kinase/Akt pathway that regulates cell proliferation, cell motility, cell survival, protein synthesis, and transcription. Rapamycin, a specific inhibitor of mTOR, suppresses lymphangiogenesis and lymphatic metastasis in PDAC cells [29].

The described proteomic approach is reproducible for analysis of membrane proteins in cultured pancreatic cancer cells. We observed consistent SDS-PAGE gel patterns for membrane proteins isolated from cultured AsPC-1 or BxPC-3 cells. To examine the reproducibility of LC-MS/MS for identification of membrane proteins, we repeated LC-MS/MS analysis of the peptides yielded from 3 gel bands. Compared to single LC-MS/MS, which identified 45 proteins in total, the duplicate LCMS/MS analyses identified 47 proteins ( $4 \%$ increase). 
Table 1 Integral to membrane proteins identified in AsPC-1 \& BxPC-3 cells

\begin{tabular}{|c|c|c|c|}
\hline \multicolumn{2}{|l|}{ AsPC-1 } & \multicolumn{2}{|l|}{ BxPC-3 } \\
\hline Accession \# & Protein name & Accession \# & Protein name \\
\hline 1A25_HUMAN & HLA class I histocompatibility antigen, A-25 alpha chain & 4F2_HUMAN & 4F2 cell-surface antigen heavy chain \\
\hline 4F2_HUMAN & 4F2 cell-surface antigen heavy chain & ACSL3_HUMAN & Long-chain-fatty-acid-CoA ligase 3 \\
\hline AAAT_HUMAN & Neutral amino acid transporter $\mathrm{B}(0)$ & ACSL4_HUMAN & Long-chain-fatty-acid-CoA ligase 4 \\
\hline ACSL5_HUMAN & Long-chain-fatty-acid-CoA ligase 5 & ADT2_HUMAN & ADP/ATP translocase 2 \\
\hline ADT2_HUMAN & ADP/ATP translocase 2 & ALK_HUMAN & ALK tyrosine kinase receptor precursor \\
\hline ANPRC_HUMAN & Atrial natriuretic peptide clearance receptor & APMAP_HUMAN & Adipocyte plasma membrane-associated protein \\
\hline AOFB_HUMAN & Amine oxidase [flavin-containing] B & AT1A1_HUMAN & Sodium/potassium-transporting ATPase subunit alpha-1 \\
\hline APMAP_HUMAN & Adipocyte plasma membrane-associated protein & CALX_HUMAN & Calnexin \\
\hline AT1A1_HUMAN & $\begin{array}{l}\text { Sodium/potassium-transporting ATPase subunit alpha-1 } \\
\text { precursor }\end{array}$ & CEAM1_HUMAN & $\begin{array}{l}\text { Carcinoembryonic antigen-related cell adhesion } \\
\text { molecule } 1\end{array}$ \\
\hline ATP7B_HUMAN & Copper-transporting ATPase 2 & CEAM6_HUMAN & $\begin{array}{l}\text { Carcinoembryonic antigen-related cell adhesion } \\
\text { molecule } 6\end{array}$ \\
\hline CALX_HUMAN & Calnexin & CKAP4_HUMAN & Cytoskeleton-associated protein 4 \\
\hline CEAM1_HUMAN & $\begin{array}{l}\text { Carcinoembryonic antigen-related cell adhesion } \\
\text { molecule } 1\end{array}$ & CLCN1_HUMAN & Chloride channel protein \\
\hline CEAM6_HUMAN & $\begin{array}{l}\text { Carcinoembryonic antigen-related cell adhesion } \\
\text { molecule } 6\end{array}$ & CMC2_HUMAN & Calcium-binding mitochondrial carrier protein Aralar2 \\
\hline CMC2_HUMAN & Calcium-binding mitochondrial carrier protein Aralar2 & CODA1_HUMAN & Collagen alpha-1 (XIII) chain \\
\hline CY1_HUMAN & Cytochrome $\mathrm{cl}$, heme protein & CSMD2_HUMAN & CUB and sushi domain-containing protein 2 \\
\hline EGFR_HUMAN & Epidermal growth factor receptor precursor & EAA1_HUMAN & Excitatory amino acid transporter 1 \\
\hline FLNB_HUMAN & Filamin-B & GP124_HUMAN & Probable G-protein coupled receptor 124 \\
\hline FLRT1_HUMAN & Leucine-rich repeat transmembrane protein FLRT1 & GRP78_HUMAN & 78 kDa glucose-regulated protein \\
\hline FZD8_HUMAN & Frizzled-8 precursor & HNRPM_HUMAN & Heterogeneous nuclear ribonucleoprotein $\mathrm{M}$ \\
\hline GRP78_HUMAN & $78 \mathrm{kDa}$ glucose-regulated protein & ITAV_HUMAN & Integrin alpha-V \\
\hline IL4RA_HUMAN & Interleukin-4 receptor alpha chain & KCNQ3_HUMAN & $\begin{array}{l}\text { Potassium voltage-gated channel subfamily KQT } \\
\text { member } 3\end{array}$ \\
\hline IMMT_HUMAN & Mitochondrial inner membrane protein & L2HDH_HUMAN & L-2-hydroxyglutarate dehydrogenase \\
\hline KCNK3_HUMAN & Potassium channel subfamily K member 3 & M2OM_HUMAN & Mitochondrial 2-oxoglutarate/malate carrier protein \\
\hline KTN1_HUMAN & Kinectin & MUC16_HUMAN & Mucin-16 \\
\hline LAMP1_HUMAN & Lysosome-associated membrane glycoprotein 1 & MYOF_HUMAN & Myoferlin \\
\hline LRC59_HUMAN & Leucine-rich repeat-containing protein 59 & OST48_HUMAN & $\begin{array}{l}\text { Dolichyl-diphosphooligosaccharide-protein } \\
\text { glycosyltransferase } 48 \text { kDa subunit }\end{array}$ \\
\hline MTCH2_HUMAN & Mitochondrial carrier homolog 2 & PCD16_HUMAN & Protocadherin-16 precursor \\
\hline MUC16_HUMAN & Mucin-16 & PGRC1_HUMAN & $\begin{array}{l}\text { Membrane-associated progesterone receptor } \\
\text { component } 1\end{array}$ \\
\hline MYOF_HUMAN & Myoferlin & PHB_HUMAN & Prohibitin \\
\hline OST48_HUMAN & $\begin{array}{l}\text { Dolichyl-diphosphooligosaccharide-protein } \\
\text { glycosyltransferase } 48 \text { kDa subunit }\end{array}$ & PK1L1_HUMAN & Polycystic kidney disease protein 1-like 1 \\
\hline PHB_HUMAN & Prohibitin & PTPRZ_HUMAN & Receptor-type tyrosine-protein phosphatase zeta \\
\hline S12A1_HUMAN & Solute carrier family 12 member 1 & SSRD_HUMAN & Translocon-associated protein subunit delta precursor \\
\hline SFXN3_HUMAN & Sideroflexin-3 & TFR1_HUMAN & Transferrin receptor protein 1 \\
\hline VAT1_HUMAN & Synaptic vesicle membrane protein VAT-1 homolog & TMEDA_HUMAN & Transmembrane emp24 domain-containing protein 10 \\
\hline VDAC2_HUMAN & Voltage-dependent anion-selective channel protein 2 & TOM40_HUMAN & $\begin{array}{l}\text { Mitochondrial import receptor subunit TOM40 } \\
\text { homolog }\end{array}$ \\
\hline VMAT2_HUMAN & Synaptic vesicular amine transporter & & \\
\hline
\end{tabular}

This suggested that the observed difference in membrane protein profiles between the two PDAC cell lines is meaningful. Our adopted approach is valid to identify large membrane proteins, which are usually difficult to analyze with 2-D gel electrophoresis (2-DE) method. In AsPC-1 cells, $35 \%$ of the identified proteins have a molecular weight above $70 \mathrm{kDa}$, whereas $43 \%$ of the proteins are larger than $70 \mathrm{kDa}$ in BxPC-3 cells. In addition to the proteins either present in AsPC-1 or in BxPC-3 cells, many other proteins were found in both cell types with a differential number of peptides matched. This may reflect the differential level of a 


\section{BxPC-3 AsPC-1}

\section{PGK1}

\section{Annexin A1}

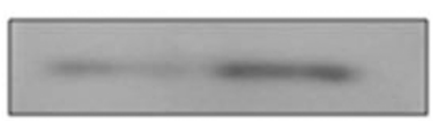

\section{Actin}

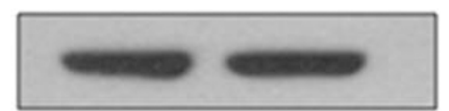

Figure 3 Western blot analysis of Annexin A1 and phosphoglycerate kinase 1 (PGK1) between AsPC-1 and BxPC-3 cells.

protein between the two cell lines, although further verification is needed. Around 50\% of the proteins identified in AsPC-1 and BxPC-3 cells are directly classified as membrane proteins, including a number of integral to membrane proteins and plasma membrane proteins. In addition, many mitochondrial inner membrane proteins were also identified from AsPC-1 $(n=21)$ and BxPC-3 $(\mathrm{n}=13)$ cells. The mitochondrial inner membrane forms internal compartments known as cristae, which allow greater space for the proteins such as cytochromes to function properly and efficiently. The inner mitochondrial membrane contains mitochondria fusion and fission proteins, ATP synthases, transporter proteins regulating metabolite flux as well as proteins that perform the redox reactions of oxidative phosphorylation, many of which were identified in this study. Among the proteins that are not classified as membrane proteins, many are either membrane-associated proteins (e.g., kinases, G proteins, or enzymes) or proteins associated with other subcellular compartments such as mitochondria, endoplasmic reticulum (ER) or nucleus (e.g., histones, elongation factors, translation initiation factor and transcription factors) (Additional file 1, Table S1). It is commonly assumed that a protein is predominantly localized in a given cellular compartment where it exerts its specific function. However, a same protein may be localized at different cell compartments or travel between different organelles and therefore exert multiple cellular functions [30]. In fact, many proteins identified in mitochondria or ER are membrane or membraneassociated proteins.

In addition, many metabolic enzymes were identified from the two PDAC cell lines, reflecting the functional role of pancreas (Tables 2 and 3). These metabolic enzymes are involved in glycolysis, tricarboxylic acid cycle, gluconeogenesis, metabolism of nucleotides, lipids/fatty acids and amino acids, protein folding/ unfolded protein response, and pantose phosphate shunt. Table 4 lists the small, membrane associated G proteins identified in AsPC-1 and BxPC-3 cells. Small GTPases regulate a wide variety of cellular processes, including growth, cellular differentiation, cell movement and lipid vesicle transport. RhoA, Rab-1A and Rab-10 were present in AsPC-1 cells whereas Rab-14 was found in BxPC-3 cells. As a proto-oncogene, RhoA regulates a signal transduction pathway linking plasma membrane receptors to the assembly of focal adhesions and actin stress fibers. On the other hand, Rab-1A regulates the 'ER-to-Golgi' transport, a bidirectional membrane traffic between the ER and Golgi apparatus which mediates the transfer of proteins by means of small vesicles or tubular-saccular extensions. Rab-10 is also involved in vesicular trafficking, particularly the directed movement of substances from the Golgi to early sorting endosomes. Mutated KRAS is a potent oncogene in PDAC. KRAS protein is usually tethered to cell membranes because of the presence of an isoprenyl group on its C-terminus. However, KRAS protein was not identified in this study, which might result from numerous mutations of the gene, hindering the matching of peptides based on molecular weight.

Some of the proteins identified from the current study may be further verified in clinical specimens as biomarkers for diagnostic/prognostic applications. Particularly, protein biomarkers may be used to classify pancreatic cancer patients for a better treatment decision. Cancer biomarker discovery is an intensive research area. Despite the fact that a large number of researchers are searching for cancer biomarkers, only a handful of protein biomarkers have been approved by the US Food and Drug Administration (FDA) for clinical use [31]. Interestingly, most of the FDAapproved protein biomarkers for human cancers are membrane proteins, including cancer antigen CA125 (ovarian), carcinoembryonic antigen (colon), epidermal growth factor receptor (colon), tyrosine-protein kinase KIT (gastrointestinal), HER2/NEU, CA15-3, CA27-29, Oestrogen receptor and progesterone receptor (breast) and bladder tumour-associated antigen (bladder) [31]. Similarly, most of the reported protein biomarkers in PDAC are of membrane origin or membrane-associated, including CA 19-9, CEA, CA 242, CA 72-4, KRAS, KAI1, CEA-related cell adhesion molecule 1 (CEACAM1), MUC1, MUC4, among many others [32-39]. For instance, CA 19-9 is a membrane carbohydrate antigen and the most commonly used biomarker in pancreatic cancers. As a cell adhesion molecule, CEA actually mediates the collagen binding of epithelial cells [40]. KAI1, a metastasis suppressor protein, belongs to the transmembrane 4 superfamily. It is up-regulated in early PDAC and down-regulated in metastatic PDAC [34]. The present study also identified CEA-related cell 
Table 2 Metabolic enzymes identified in AsPC-1 cells

\begin{tabular}{|c|c|c|c|c|c|c|}
\hline Protein name & Accession \# & $\begin{array}{l}\text { Unique } \\
\text { peptides }\end{array}$ & $\begin{array}{c}\text { Total } \\
\text { peptides }\end{array}$ & $\begin{array}{l}\mathrm{Mr} \\
\text { (Kda) }\end{array}$ & PI & Biological process \\
\hline $\begin{array}{l}\text { 2-oxoglutarate dehydrogenase E1 component, } \\
\text { mitochondrial precursor }\end{array}$ & ODO1_HUMAN & 8 & 18 & 115.9 & 6.39 & Glycolysis \\
\hline $\begin{array}{l}\text { 3,2-trans-enoyl-CoA isomerase, mitochondrial } \\
\text { precursor }\end{array}$ & D3D2_HUMAN & 3 & 13 & 32.8 & 8.8 & Fatty acid metabolism; Lipid metabolism \\
\hline 3-hydroxyacyl-CoA dehydrogenase type-2 & HCD2_HUMAN & 6 & 10 & 26.9 & 7.65 & Lipid metabolic process; tRNA processing \\
\hline $\begin{array}{l}\text { 3-hydroxyisobutyrate dehydrogenase, } \\
\text { mitochondrial precursor }\end{array}$ & 3HIDH_HUMAN & 7 & 16 & 35.3 & 8.38 & $\begin{array}{l}\text { Pentose-phosphate shunt; valine metabolic } \\
\text { process }\end{array}$ \\
\hline 3-ketoacyl-CoA thiolase, peroxisomal precursor & THIK_HUMAN & 3 & 4 & 44.3 & 8.76 & Fatty acid metabolism; Lipid metabolism \\
\hline 3-mercaptopyruvate sulfurtransferase & THTM_HUMAN & 3 & 7 & 33.2 & 6.13 & Cyanate catabolic process \\
\hline 78 kDa glucose-regulated protein & GRP78_HUMAN & 7 & 12 & 72.3 & 5.07 & $\begin{array}{l}\text { ER-associated protein catabolic process; ER } \\
\text { unfolded protein response; ER regulation of } \\
\text { protein folding }\end{array}$ \\
\hline $\begin{array}{l}\text { Acetyl-CoA acetyltransferase, mitochondrial } \\
\text { precursor }\end{array}$ & THIL_HUMAN & 2 & 6 & 45.2 & 8.98 & Ketone body metabolism \\
\hline Aconitate hydratase, mitochondrial & ACON_HUMAN & 2 & 3 & 85.4 & 7.36 & Tricarboxylic acid cycle \\
\hline Acyl-protein thioesterase 1 & LYPA1_HUMAN & 2 & 2 & 24.7 & 6.29 & Fatty acid metabolism; Lipid metabolism \\
\hline Adenylate kinase 2, mitochondrial & KAD2_HUMAN & 7 & 20 & 26.5 & 7.67 & Nucleic acid metabolic process \\
\hline ADP/ATP translocase 2 & ADT2_HUMAN & 5 & 11 & 32.9 & 9.76 & Transmembrane transporter activity \\
\hline Aldehyde dehydrogenase, mitochondrial & ALDH2_HUMAN & 3 & 7 & 56.3 & 6.63 & Alcohol metabolic process \\
\hline Alpha-enolase & ENOA_HUMAN & 2 & 2 & 47.1 & 7.01 & Glycolysis \\
\hline Amine oxidase B & AOFB_HUMAN & 2 & 2 & 58.7 & 7.2 & Oxidation reduction \\
\hline Aspartate aminotransferase, mitochondrial & AATM_HUMAN & 4 & 6 & 47.4 & 9.14 & Lipid transport \\
\hline ATP synthase subunit alpha, mitochondrial & ATPA_HUMAN & 21 & 52 & 59.7 & 9.16 & ATP synthesis \\
\hline ATP synthase subunit d, mitochondrial & ATP5H_HUMAN & 3 & 7 & 18.5 & 5.21 & ATP synthesis; Ion transport \\
\hline ATP synthase subunit b, mitochondrial & AT5F1_HUMAN & 2 & 3 & 28.9 & 9.37 & ATP synthesis \\
\hline ATP synthase subunit beta, mitochondrial & ATPB_HUMAN & 28 & 95 & 56.5 & 5.26 & ATP synthesis \\
\hline ATP synthase subunit $\mathrm{f}$, mitochondrial & ATPK_HUMAN & 2 & 2 & 10.9 & 9.7 & ATP synthesis; Ion transport \\
\hline ATP synthase subunit gamma, mitochondrial; & ATPG_HUMAN & 3 & 6 & 33 & 9.23 & ATP synthesis; proton transport \\
\hline ATP synthase subunit $O$, mitochondrial & ATPO_HUMAN & 6 & 11 & 23.3 & 9.97 & $\begin{array}{l}\text { ATP synthesis, ion transport; ATP catabolic } \\
\text { process }\end{array}$ \\
\hline $\begin{array}{l}\text { Calcium-binding mitochondrial carrier protein } \\
\text { Aralar2 }\end{array}$ & CMC2_HUMAN & 7 & 16 & 74.1 & 7.14 & $\begin{array}{l}\text { Mitochondrial aspartate and glutamate } \\
\text { carrier }\end{array}$ \\
\hline Citrate synthase, mitochondrial precursor & CISY_HUMAN & 2 & 3 & 51.7 & 8.45 & Tricarboxylic acid cycle \\
\hline Cytochrome b5 type B & CYB5B_HUMAN & 2 & 4 & 16.3 & 4.88 & Electron transport \\
\hline $\begin{array}{l}\text { Cytochrome b-c1 complex subunit } 1 \text {, } \\
\text { mitochondrial }\end{array}$ & QCR1_HUMAN & 6 & 12 & 52.6 & 5.94 & Electron transport \\
\hline $\begin{array}{l}\text { Cytochrome b-c1 complex subunit 2, } \\
\text { mitochondrial }\end{array}$ & QCR2_HUMAN & 3 & 4 & 48.4 & 8.74 & $\begin{array}{l}\text { Aerobic respiration; electron transport } \\
\text { chain; oxidative phosphorylation }\end{array}$ \\
\hline Cytochrome c oxidase subunit 2 & COX2_HUMAN & 2 & 6 & 25.5 & 4.67 & Electron transport chain \\
\hline Cytochrome $\mathrm{cl}$, heme protein, mitochondrial & CY1_HUMAN & 5 & 10 & 35.4 & 9.15 & Electron transport chain \\
\hline Cytochrome $\mathrm{cl}$, heme protein, mitochondrial & CY1_HUMAN & 2 & 3 & 35.4 & 9.15 & Electron transport chain \\
\hline $\begin{array}{l}\text { D-beta-hydroxybutyrate dehydrogenase, } \\
\text { mitochondrial precursor }\end{array}$ & BDH_HUMAN & 2 & 3 & 38.1 & 9.1 & Oxidation reduction \\
\hline $\begin{array}{l}\text { Delta(3,5)-Delta(2,4)-dienoyl-CoA isomerase, } \\
\text { mitochondrial }\end{array}$ & ECH1_HUMAN & 4 & 10 & 35.8 & 8.16 & Fatty acid metabolism; Lipid metabolism \\
\hline Delta-1-pyrroline-5-carboxylate synthetase & P5CS_HUMAN & 2 & 4 & 87.2 & 6.66 & $\begin{array}{l}\text { Amino-acid biosynthesis; Proline } \\
\text { biosynthesis }\end{array}$ \\
\hline Dihydrolipoyl dehydrogenase, mitochondrial & DLDH_HUMAN & 7 & 16 & 54.1 & 7.95 & Cell redox homeostasis \\
\hline $\begin{array}{l}\text { Dihydrolipoyllysine-residue acetyltransferase } \\
\text { component of pyruvate dehydrogenase complex, } \\
\text { mitochondrial }\end{array}$ & ODP2_HUMAN & 3 & 5 & 65.7 & 7.96 & Glycolysis \\
\hline Dihydrolipoyllysine-residue succinyltransferase & ODO2_HUMAN & 4 & 7 & 48.6 & 9.01 & Tricarboxylic acid cycle \\
\hline
\end{tabular}
component of 2-oxoglutarate dehydrogenase complex, mitochondrial 
Table 2 Metabolic enzymes identified in AsPC-1 cells (Continued)

Electron transfer flavoprotein subunit alpha, mitochondrial

Electron transfer flavoprotein subunit beta

Endoplasmin

Enoyl-CoA hydratase, mitochondrial

Glutamate dehydrogenase 1, mitochondrial;

Glyceraldehyde-3-phosphate dehydrogenase

Glycerol-3-phosphate dehydrogenase, mitochondrial precursor

Haloacid dehalogenase-like hydrolase domaincontaining protein 3

Histidine triad nucleotide-binding protein 2

Hyaluronidase-3

Hydroxyacyl-coenzyme A dehydrogenase, mitochondrial precursor

Isoleucyl-tRNA synthetase, mitochondrial precursor

Isovaleryl-CoA dehydrogenase, mitochondrial

L-lactate dehydrogenase A chain

Lon protease homolog, mitochondrial

Long-chain-fatty-acid-CoA ligase 5;

Malate dehydrogenase, mitochondrial

Medium-chain specific acyl-CoA dehydrogenase, mitochondrial

Mitochondrial carrier homolog 2

Mitochondrial inner membrane protein

$\mathrm{NADH}$-cytochrome b5 reductase 3

Neutral alpha-glucosidase $A B$

Peptidyl-prolyl cis-trans isomerase A

Peroxiredoxin-5

Phosphoenolpyruvate carboxykinase,

mitochondrial

Phosphoglycerate kinase 1

Protein disulfide-isomerase

Protein disulfide-isomerase A3

Protein disulfide-isomerase A4

Protein disulfide-isomerase A6

Protein ETHE1, mitochondrial

Protein transport protein Sec16A

Pyruvate dehydrogenase E1 component alpha subunit, somatic form

Pyruvate dehydrogenase E1 component subunit alpha, mitochondrial precursor

Pyruvate dehydrogenase E1 component subunit beta, mitochondrial

Serine hydroxymethyltransferase, mitochondrial

Succinate dehydrogenase flavoprotein subunit, mitochondrial

Succinyl-CoA ligase [GDP-forming] beta-chain, mitochondrial precursor

\begin{tabular}{|c|c|c|c|c|c|}
\hline ETFA_HUMAN & 2 & 5 & 35.1 & 8.62 & Electron transport \\
\hline ETFB_HUMAN & 4 & 6 & 27.8 & 8.25 & Electron transport \\
\hline ENPL_HUMAN & 16 & 28 & 92.4 & 4.76 & $\begin{array}{l}\text { ER-associated protein catabolic process; } \\
\text { protein folding/transport; response to } \\
\text { hypoxia }\end{array}$ \\
\hline ECHM_HUMAN & 9 & 26 & 31.4 & 8.34 & Fatty acid metabolism; Lipid metabolism \\
\hline DHE3_HUMAN & 3 & 4 & 61.4 & 7.66 & Glutamate metabolism \\
\hline G3P_HUMAN & 5 & 7 & 36 & 8.57 & Glycolysis \\
\hline GPDM_HUMAN & 8 & 15 & 80.8 & 7.23 & Glycolysis \\
\hline HDHD3_HUMAN & 3 & 4 & 28 & 6.21 & $\begin{array}{l}\text { Metabolic process phosphoglycolate } \\
\text { phosphatase activity }\end{array}$ \\
\hline HINT2_HUMAN & 2 & 3 & 17.2 & 9.2 & Lipid synthesis; Steroid biosynthesis \\
\hline HYAL3_HUMAN & 2 & 2 & 46.5 & & Carbohydrate metabolic process \\
\hline HCDH_HUMAN & 2 & 4 & 34.3 & 8.88 & Fatty acid metabolism; Lipid metabolism \\
\hline SYIM_HUMAN & 5 & 7 & 113.7 & 6.78 & Protein biosynthesis \\
\hline IVD_HUMAN| & 2 & 2 & 46.3 & 8.45 & $\begin{array}{l}\text { Leucine catabolic process; Oxidation } \\
\text { reduction }\end{array}$ \\
\hline LDHA_HUMAN & 3 & 5 & 36.7 & 8.84 & Glycolysis \\
\hline LONM_HUMAN & 2 & 2 & 106.4 & 6.01 & Required for intramitochondrial proteolysis \\
\hline ACSL5_HUMAN & 2 & 4 & 75.9 & 6.49 & Fatty acid metabolism; Lipid metabolism \\
\hline MDHM_HUMAN & 3 & 5 & 35.5 & 8.92 & Tricarboxylic acid cycle; Glycolysis \\
\hline ACADM_HUMAN & 2 & 6 & 46.6 & 8.61 & Fatty acid metabolism; Lipid metabolism \\
\hline MTCH2_HUMAN & 3 & 10 & 33.3 & 8.25 & Transmembrane transport \\
\hline IMMT_HUMAN & 2 & 2 & 83.6 & 6.08 & Protein binding; Cell proliferation-inducing \\
\hline NB5R3_HUMAN & 3 & 3 & 34.2 & 7.18 & $\begin{array}{l}\text { Cholesterol biosynthesis; Lipid/steroid } \\
\text { synthesis }\end{array}$ \\
\hline GANAB_HUMAN & 6 & 9 & 106.8 & 5.74 & Carbohydrate metabolic process \\
\hline PPIA_HUMAN & 2 & 3 & 18 & 7.68 & Protein folidng; Interspecies interation \\
\hline PRDX5_HUMAN & 2 & 5 & 22 & 8.85 & Cell redox homeostasis \\
\hline PPCKM_HUMAN & 8 & 18 & 70.6 & 7.56 & Gluconeogenesis \\
\hline PGK1_HUMAN & 4 & 7 & 44.6 & 8.3 & Glycolysis \\
\hline PDIA1_HUMAN & 3 & 3 & 57.1 & 4.76 & Cell redox homeostasis \\
\hline PDIA3_HUMAN & 4 & 7 & 56.7 & 5.98 & Cell redox homeostasis \\
\hline PDIA4_HUMAN & 2 & 2 & 72.9 & 4.96 & Cell redox homeostasis; Protein secretion \\
\hline PDIA6_HUMAN & 2 & 3 & 48.1 & 4.95 & Cell redox homeostasis; Protein folding \\
\hline ETHE1_HUMAN & 4 & 11 & 27.9 & 6.35 & Metabolic homeostasis in mitochondria \\
\hline SC16A_HUMAN & 2 & 2 & 233.4 & 5.4 & ER-Golgi transport; Protein transport \\
\hline ODPA_HUMAN & 2 & 4 & 43.3 & 8.35 & Glycolysis \\
\hline ODPAT_HUMAN & 3 & 7 & 42.9 & 8.76 & Glycolysis \\
\hline ODPB_HUMAN & 2 & 3 & 39.2 & 6.2 & Glycolysis; Tricarboxylic acid cycle \\
\hline GLYM_HUMAN & 12 & 21 & 56 & 8.76 & $\begin{array}{l}\text { L-serine metabolic process; Glycine } \\
\text { metabolic process; One-carbon metabolic } \\
\text { process }\end{array}$ \\
\hline DHSA_HUMAN & 2 & 5 & 72.6 & 7.06 & Electron transport; Tricarboxylic acid cycle \\
\hline SUCB2_HUMAN & 3 & 3 & 46.5 & 6.15 & $\begin{array}{l}\text { Succinyl-CoA metabolic process; } \\
\text { Tricarboxylic acid cycle }\end{array}$ \\
\hline
\end{tabular}


Table 2 Metabolic enzymes identified in AsPC-1 cells (Continued)

\begin{tabular}{|c|c|c|c|c|c|c|}
\hline $\begin{array}{l}\text { Succinyl-CoA ligase [GDP-forming] subunit alpha, } \\
\text { mitochondrial precursor }\end{array}$ & SUCA_HUMAN & 2 & 5 & 35 & 9.01 & Tricarboxylic acid cycle \\
\hline Superoxide dismutase $[\mathrm{Mn}]$, mitochondrial & SODM_HUMAN & 2 & 5 & 24.7 & 8.35 & Elimination of radicals \\
\hline Thioredoxin-dependent peroxide reductase & PRDX3_HUMAN & 4 & 10 & 27.7 & 7.68 & $\begin{array}{l}\text { Cell redox homeostasis; Hydrogen peroxide } \\
\text { catabolic process }\end{array}$ \\
\hline Thiosulfate sulfurtransferase & THTR_HUMAN & 2 & 3 & 33.4 & 6.77 & Cyanate catabolic process \\
\hline $\begin{array}{l}\text { Trifunctional enzyme subunit alpha, } \\
\text { mitochondrial }\end{array}$ & ECHA_HUMAN & 17 & 46 & 82.9 & 9.16 & Fatty acid metabolism; Lipid metabolism \\
\hline Trifunctional enzyme subunit beta, mitochondrial & ECHB_HUMAN & 6 & 12 & 51.3 & 9.45 & Fatty acid metabolism \\
\hline Trimethyllysine dioxygenase, mitochondrial & TMLH_HUMAN & 2 & 3 & 49.5 & 7.64 & Carnitine biosynthesis \\
\hline $\begin{array}{l}\text { Very long-chain specific acyl-CoA dehydrogenase, } \\
\text { mitochondrial }\end{array}$ & ACADV_HUMAN & 3 & 5 & 70.3 & 8.92 & Fatty acid metabolism; Lipid metabolism \\
\hline
\end{tabular}

Table 3 Metabolic enzymes identified in BxPC-3 cells

\begin{tabular}{|c|c|c|c|c|c|c|}
\hline Protein name & Accession \# & $\begin{array}{l}\text { Unique } \\
\text { peptides }\end{array}$ & $\begin{array}{c}\text { Total } \\
\text { peptides }\end{array}$ & $\begin{array}{c}\mathrm{Mr} \\
(\mathrm{KDa})\end{array}$ & $\mathrm{PI}$ & Biological process \\
\hline $\begin{array}{l}\text { 2-oxoglutarate dehydrogenase E1 component, } \\
\text { mitochondrial }\end{array}$ & ODO1_HUMAN & 4 & 4 & 115.9 & 6.39 & Glycolysis \\
\hline 3-ketoacyl-CoA thiolase, mitochondrial & THIM_HUMAN & 2 & 4 & 41.9 & 8.32 & Fatty acid metabolism Lipid metabolism \\
\hline 78 kDa glucose-regulated protein & GRP78_HUMAN & 31 & 91 & 72.3 & 5.07 & $\begin{array}{l}\text { ER-associated protein catabolic process ER } \\
\text { unfolded protein response ER regulation of } \\
\text { protein folding }\end{array}$ \\
\hline Adenylate kinase 2, mitochondrial & KAD2_HUMAN & 4 & 7 & 26.5 & 7.67 & Nucleotide/nucleic acid metabolic process \\
\hline ADP/ATP translocase 2 & ADT2_HUMAN & 2 & 5 & 32.9 & 9.76 & Transmembrane transporter activity \\
\hline Alpha-aminoadipic semialdehyde dehydrogenase & AL7A1_HUMAN & 2 & 2 & 55.3 & 6.44 & $\begin{array}{l}\text { Cellular aldehyde metabolic process; } \\
\text { oxidation reduction }\end{array}$ \\
\hline Alpha-enolase & ENOA_HUMAN & 3 & 5 & 47.1 & 7.01 & Glycolysis \\
\hline Annexin A1 & ANXA1_HUMAN & 4 & 5 & 38.7 & 6.57 & $\begin{array}{l}\text { Anti-apoptosis; Exocytosis; Lipid metabolic } \\
\text { process }\end{array}$ \\
\hline $\begin{array}{l}\text { Aspartate aminotransferase, mitochondrial } \\
\text { precursor }\end{array}$ & AATM_HUMAN & 2 & 7 & 47.4 & 9.14 & Lipid transport \\
\hline ATP synthase subunit alpha, mitochondrial & ATPA_HUMAN & 3 & 6 & 59.7 & 9.16 & ATP synthesis \\
\hline ATP synthase subunit beta, mitochondrial & ATPB_HUMAN & 4 & 13 & 56.5 & 5.26 & ATP synthesis \\
\hline ATP synthase subunit $d$, mitochondrial & ATP5H_HUMAN & 2 & 4 & 18.5 & 5.21 & ATP synthesis; lon transport \\
\hline ATP synthase subunit gamma, mitochondrial & ATPG_HUMAN & 2 & 3 & 33 & 9.23 & ATP synthesis; Proton transport \\
\hline ATP synthase subunit $O$, mitochondrial & ATPO_HUMAN & 2 & 3 & 23.3 & 9.97 & $\begin{array}{l}\text { ATP synthesis; Ion transport ATP catabolic } \\
\text { process }\end{array}$ \\
\hline $\begin{array}{l}\text { Calcium-binding mitochondrial carrier protein } \\
\text { Aralar2 }\end{array}$ & CMC2_HUMAN & 2 & 4 & 74.1 & 7.14 & $\begin{array}{l}\text { Mitochondrial aspartate and glutamate } \\
\text { carrier }\end{array}$ \\
\hline Citrate synthase, mitochondrial; & CISY_HUMAN & 3 & 5 & 51.7 & 8.45 & Tricarboxylic acid cycle \\
\hline $\begin{array}{l}\text { Cytochrome b-c1 complex subunit } 1, \\
\text { mitochondrial }\end{array}$ & QCR1_HUMAN & 3 & 5 & 52.6 & 5.94 & Electron transport \\
\hline $\begin{array}{l}\text { Cytochrome b-c1 complex subunit } 2 \text {, } \\
\text { mitochondrial }\end{array}$ & QCR2_HUMAN & 2 & 2 & 48.4 & 8.74 & $\begin{array}{l}\text { Aerobic respiration; Electron transport } \\
\text { chain; Oxidative phosphorylation }\end{array}$ \\
\hline Cytochrome c oxidase subunit 2 & COX2_HUMAN & 2 & 4 & 25.5 & 4.67 & Electron transport chain \\
\hline $\begin{array}{l}\text { Cytochrome c oxidase subunit 5B, mitochondrial } \\
\text { precursor }\end{array}$ & COX5B_HUMAN & 2 & 2 & 13.7 & 9.07 & Respiratory gaseous exchange \\
\hline $\begin{array}{l}\text { Delta(3,5)-Delta(2,4)-dienoyl-CoA isomerase, } \\
\text { mitochondrial precursor }\end{array}$ & ECH1_HUMAN & 2 & 6 & 35.8 & 8.16 & Fatty acid metabolism; Lipid metabolism \\
\hline Delta-1-pyrroline-5-carboxylate synthetase & P5CS_HUMAN & 2 & 3 & 87.2 & 6.66 & $\begin{array}{l}\text { Amino-acid biosynthesis; Proline } \\
\text { biosynthesis }\end{array}$ \\
\hline Dihydrolipoyl dehydrogenase, mitochondrial & DLDH_HUMAN & 5 & 13 & 54.1 & 7.95 & Cell redox homeostasis \\
\hline Dihydrolipoyllysine-residue succinyltransferase & ODO2_HUMAN & 3 & 6 & 48.6 & 9.01 & Tricarboxylic acid cycle \\
\hline
\end{tabular}


Table 3 Metabolic enzymes identified in BxPC-3 cells (Continued)

\begin{tabular}{|c|c|c|c|c|c|c|}
\hline $\begin{array}{l}\text { Electron transfer flavoprotein subunit alpha, } \\
\text { mitochondrial }\end{array}$ & ETFA_HUMAN & 3 & 7 & 35.1 & 8.62 & Electron transport \\
\hline Electron transfer flavoprotein subunit beta & ETFB_HUMAN & 2 & 3 & 27.8 & 8.25 & Electron transport \\
\hline Endoplasmin & ENPL_HUMAN & 16 & 31 & 92.4 & 4.76 & $\begin{array}{l}\text { ER-associated protein catabolic process; } \\
\text { protein folding/transport; response to } \\
\text { hypoxia }\end{array}$ \\
\hline Enoyl-CoA hydratase, mitochondrial & ECHM_HUMAN & 3 & 12 & 31.4 & 8.34 & Fatty acid metabolism; Lipid metabolism \\
\hline ERO1-like protein alpha precursor & ERO1A_HUMAN & 2 & 3 & 54.4 & 5.48 & Electron transport \\
\hline Glucosidase 2 subunit beta & GLU2B_HUMAN & 2 & 5 & 59.4 & 4.33 & ER protein kinase cascade \\
\hline Glutamate dehydrogenase 1, mitochondrial & DHE3_HUMAN & 2 & 2 & 61.4 & 7.66 & Glutamate metabolism \\
\hline Glyceraldehyde-3-phosphate dehydrogenase & G3P_HUMAN & 2 & 2 & 36 & 8.57 & Glycolysis \\
\hline $\begin{array}{l}\text { Glycerol-3-phosphate dehydrogenase, } \\
\text { mitochondrial }\end{array}$ & GPDM_HUMAN & 2 & 4 & 80.8 & 7.23 & Glycolysis \\
\hline Heme oxygenase 2 & HMOX2_HUMAN & 2 & 4 & 36 & 5.31 & $\begin{array}{l}\text { Heme oxidation; Oxidation reduction; } \\
\text { Response to hypoxia }\end{array}$ \\
\hline Hexokinase-1 & HXK1_HUMAN & 2 & 3 & 102.4 & 6.36 & Glycolysis \\
\hline $\begin{array}{l}\text { L-2-hydroxyglutarate dehydrogenase, } \\
\text { mitochondrial }\end{array}$ & L2HDH_HUMAN & 2 & 2 & 50.3 & 8.57 & $\begin{array}{l}\text { Cellular protein metabolic process; } \\
\text { Oxidation reduction }\end{array}$ \\
\hline Lon protease homolog, mitochondrial & LONM_HUMAN & 2 & 2 & 106.4 & 6.01 & Required for intramitochondrial proteolysis \\
\hline Long-chain-fatty-acid-CoA ligase 3 & ACSL3_HUMAN & 2 & 3 & 80.4 & 8.65 & Fatty acid metabolism; Lipid metabolism \\
\hline Long-chain-fatty-acid-CoA ligase 4 & ACSL4_HUMAN & 2 & 3 & 79.1 & 8.66 & Fatty acid metabolism; Lipid metabolism \\
\hline Malate dehydrogenase, mitochondrial & MDHM_HUMAN & 3 & 4 & 35.5 & 8.92 & TCA glycolysis \\
\hline $\begin{array}{l}\text { Medium-chain specific acyl-CoA dehydrogenase, } \\
\text { mitochondrial }\end{array}$ & ACADM_HUMAN| & 2 & 3 & 46.6 & 8.61 & Fatty acid metabolism; Lipid metabolism \\
\hline Methylenetetrahydrofolate reductase & MTHR_HUMAN & 2 & 2 & 74.5 & 5.22 & $\begin{array}{l}\text { Methionine metabolic process; Oxidation } \\
\text { reduction }\end{array}$ \\
\hline $\begin{array}{l}\text { Mitochondrial 2-oxoglutarate/malate carrier } \\
\text { protein }\end{array}$ & M2OM_HUMAN & 2 & 2 & 34 & 9.92 & Transport \\
\hline $\begin{array}{l}\text { Mitochondrial import receptor subunit TOM } 40 \\
\text { homolog }\end{array}$ & TOM40_HUMAN & 3 & 3 & 37.9 & 6.79 & Ion transport; Protein transport \\
\hline Neutral alpha-glucosidase $A B$ & GANAB_HUMAN & 7 & 10 & 106.8 & 5.74 & Carbohydrate metabolic process \\
\hline Neutral cholesterol ester hydrolase 1 & ADCL1_HUMAN & 2 & 4 & 45.8 & 6.76 & Lipid degradation \\
\hline $\begin{array}{l}\text { Ornithine aminotransferase, mitochondrial } \\
\text { precursor }\end{array}$ & OAT_HUMAN & 4 & 6 & 48.5 & 6.57 & Mitochondrial matrix protein binding \\
\hline $\begin{array}{l}\text { Phosphoenolpyruvate carboxykinase, } \\
\text { mitochondrial }\end{array}$ & PPCKM_HUMAN & 2 & 3 & 70.6 & 7.56 & Gluconeogenesis \\
\hline Protein disulfide-isomerase & PDIA1_HUMAN & 8 & 14 & 57.1 & 4.76 & Cell redox homeostasis \\
\hline Protein disulfide-isomerase $\mathrm{A} 3$ & PDIA3_HUMAN & 16 & 25 & 56.7 & 5.98 & Cell redox homeostasis \\
\hline Protein disulfide-isomerase A4 & PDIA4_HUMAN & 7 & 11 & 72.9 & 4.96 & Cell redox homeostasis; Protein secretion \\
\hline Protein disulfide-isomerase A6 & PDIA6_HUMAN & 2 & 4 & 48.1 & 4.95 & Cell redox homeostasis; Protein folding \\
\hline Pyruvate kinase isozymes M1/M2 & KPYM_HUMAN & 5 & 7 & 57.9 & 7.96 & Glycolysis; Programmed cell death \\
\hline $\begin{array}{l}\text { Serine hydroxymethyltransferase, mitochondrial } \\
\text { precursor }\end{array}$ & GLYM_HUMAN & 2 & 4 & 56 & 8.76 & $\begin{array}{l}\text { L-serine metabolic process; Glycine } \\
\text { metabolic process; One-carbon metabolic } \\
\text { process }\end{array}$ \\
\hline Sterol regulatory element-binding protein 2 & SRBP2_HUMAN & 2 & 2 & 123.6 & 8.72 & $\begin{array}{l}\text { Cholesterol metabolism; Lipid metabolism; } \\
\text { Steroid metabolism; }\end{array}$ \\
\hline $\begin{array}{l}\text { Succinate dehydrogenase flavoprotein subunit, } \\
\text { mitochondrial }\end{array}$ & DHSA_HUMAN & 3 & 10 & 72.6 & 7.06 & Electron transport; Tricarboxylic acid cycle \\
\hline $\begin{array}{l}\text { Succinyl-CoA:3-ketoacid-coenzyme A transferase } \\
1\end{array}$ & SCOT_HUMAN & 2 & 5 & 56.1 & 7.13 & Ketone body catabolic process \\
\hline Sulfide:quinone oxidoreductase, mitochondrial & SQRD_HUMAN & 6 & 9 & 49.9 & 9.18 & Oxidation reduction \\
\hline Superoxide dismutase $[\mathrm{Mn}]$, mitochondrial & SODM_HUMAN & 2 & 5 & 24.7 & 8.35 & Elimination of radicals \\
\hline $\begin{array}{l}\text { Transmembrane emp24 domain-containing } \\
\text { protein } 10\end{array}$ & TMEDA_HUMAN & 2 & 3 & 25 & 6.98 & ER-Golgi protein transport \\
\hline $\begin{array}{l}\text { Trifunctional enzyme subunit alpha, } \\
\text { mitochondrial }\end{array}$ & ECHA_HUMAN & 4 & 7 & 82.9 & 9.16 & Fatty acid metabolism; Lipid metabolism \\
\hline Trifunctional enzyme subunit beta, mitochondrial & ECHB_HUMAN & 2 & 4 & 51.3 & 9.45 & Fatty acid metabolism \\
\hline
\end{tabular}


Table 4 A list of small G proteins identified in AsPC-1 and BxPC-3 cells

\section{AsPC-1}

Ras-related protein Rab-1B

Ras-related protein Rab-1A

Ras-related protein Rab-10;

Ras-related protein Rab-2A

Ras GTPase-activating-like protein IQGAP1

Transforming protein RhoA

$\begin{array}{lll}3 & 7 & 22.2\end{array}$

$3 \quad 5 \quad 23.5$

$\begin{array}{lll}3 & 7 & 22.7\end{array}$

$2 \quad 6 \quad 22.5$

8.58

3323.5

6.08

$\begin{array}{lll}2 & 2 & 189.1\end{array}$

$\begin{array}{lll}2 & 3 & 21.8\end{array}$
RAB1B_HUMAN

WDNTTAKEF ADSLGIPFLE TSAK

WDNTTAKEF ADSLGIPFLE TSAK

EFADSLGIPF LETSAK

EFADSLGIPF LETSAK

EFADSLGIPF LETSAK

EFADSLGIPF LETSAK

NATNVEQAFM TMAAEIK

RAB7A_HUMAN DPENFPFWL GNKIDLENR

DPENFPFWL GNKIDLENR

DPENFPFWL GNK

EAINVEQAFQ TIAR

EAINVEQAFQ TIAR

RAB1A_HUMAN

WDYTTAKEF ADSLGIPFLE TSAK

WDYTTAKEF ADSLGIPFLE TSAK

EFADSLGIPF LETSAK

EFADSLGIPF LETSAK

EFADSLGIPF LETSAK

EFADSLGIPF LETSAK

NATNVEQSFM TMAAEIK

LLLIGDSGVG K

LLLIGDSGVG K

AFLTLAEDIL R

AFLTLAEDIL $R$

AFLTLAEDIL $R$

AFLTLAEDIL $R$

YIIIGDTGVG K

TASNVEEAFI NTAK

IGPQHAATNA THAGNQGGQQ AGGGCC

ILAIGLINEA LDEGDAQK

FQPGETLTEI LETPATSEQE AEHQR

QVELALWDTA GQEDYDR

QVELALWDTA GQEDYDR

HFCPNVPIL VGNKK

\section{BxPC-3}

Ras-related protein Rab-2A

Ras-related protein Rab-1B

Ras-related protein Rab-7a

Ras-related protein Rab-14

$\begin{array}{lll}2 & 3 & 23.5\end{array}$

6.08

3

$8 \quad 22$

5.55

RAB1B_HUMAN
GAAGALLVYD ITR

TASNVEEAFI NTAK

TASNVEEAFI NTAK

WDNTTAKEF ADSLGIPFLE TSAK

WDNTTAKEF ADSLGIPFLE TSAK

WDNTTAKEF ADSLGIPFLE TSAK

EFADSLGIPF LETSAK

EFADSLGIPF LETSAK

EFADSLGIPF LETSAK

EFADSLGIPF LETSAK

NATNVEQAFM TMAAEIK

DPENFPFWL GNK

EAINVEQAFQ TIAR

EAINVEQAFQ TIAR

TGENVEDAFL EAAKK

TGENVEDAFL EAAK 
Table 4 A list of small G proteins identified in AsPC-1 and BxPC-3 cells (Continued)

\begin{tabular}{|c|c|c|c|c|c|c|}
\hline Cell division control protein 42 homolog & 2 & 3 & 21.3 & 5.76 & CDC42_HUMAN & $\begin{array}{l}\text { TPFLLVGTQI DLRDDPSTIE K } \\
\text { TPFLLVGTQI DLRDDPSTIE K } \\
\text { TPFLLVGTQI DLR }\end{array}$ \\
\hline Guanine nucleotide-binding protein subunit beta- 2 & 2 & 4 & 37.3 & 5.6 & GBB2_HUMAN & $\begin{array}{l}\text { SELEQLRQEA EQLR } \\
\text { SELEQLRQEA EQLR } \\
\text { KACGDSTLTQ ITAGLDPVGR } \\
\text { KACGDSTLTQ ITAGLDPVGR }\end{array}$ \\
\hline
\end{tabular}

adhesion molecule 1, CEA-related cell adhesion molecule 6, 4F2 cell-surface antigen heavy chain (a.k.a., CD98), epidermal growth factor receptor (EGFR), hypoxia up-regulated protein 1, MUC16 and mTOR, which may be further verified in clinical specimens as biomarkers for PDAC.

In summary, we have demonstrated a proteomic approach for analysis and identification of membrane proteins in primary and metastatic PDAC cells. Many of the identified proteins are known to be modulators of cell-to-cell adhesion and tumor cell invasion. With the potential targets derived from the present study, we will next focus on promising candidates and explore their functional role in cell proliferation, apoptosis or metabolism in PDAC. Similar membrane proteomics approach can be applied to tissue specimens from patients with primary and metastatic tumors to reveal membrane protein targets for prognostic application or therapeutic intervention.

\section{Additional material}

Additional file 1: Membrane and membrane-associated proteins identified in AsPC-1 cells (Table S1) and BxPC-3 cells (Table S2). Highlighted proteins were only found in AsPC-1 cells (Table S1) and BxPC-3 cells (Table S2).

\section{Author details}

${ }^{1}$ UCLA School of Dentistry \& Dental Research Institute, Los Angeles, CA, 90095, USA. ${ }^{2}$ UCLA Center of Excellence in Pancreatic Diseases, Los Angeles, CA 90095, USA. ${ }^{3}$ UCLA Jonsson Comprehensive Cancer Center, Los Angeles, CA 90095, USA.

\section{Authors' contributions}

$\mathrm{SH}$ conceived of the study, participated in its design and coordination and drafted the manuscript. XJL and $M Z$ participated in the study design and collected the data. VLWG participated in the study design and critically reviewed the manuscript. All authors read and approved the final manuscript.

\section{Competing interests}

The authors declare that they have no competing interests.

Received: 5 May 2010 Accepted: 13 September 2010 Published: 13 September 2010

\section{References}

1. Hines OJ, Reber HA: Pancreatic neoplasms. Curr Opin Gastroenterol 2004, 20(5):452-458.
2. Jaffee EM, Hruban RH, Canto M, Kern SE: Focus on pancreas cancer. Cancer Cell 2002, 2(1):25-28.

3. Real FX: A "catastrophic hypothesis" for pancreas cancer progression. Gastroenterol 2003, 124(7):1958-1964.

4. Amado RG, Rosen LS, Hecht JR, Lin LS, Rosen PJ: Low-dose trimetrexate glucuronate and protracted 5 -fluorouracil infusion in previously untreated patients with advanced pancreatic cancer. Ann Oncol 2002, 13(4):582-588.

5. Wu CC, MacCoss MJ, Howell KE, Yates JR: A method for the comprehensive proteomic analysis of membrane proteins. Nat Biotech 2003, 21(5):532-538.

6. Wu CC, Yates JR: The application of mass spectrometry to membrane proteomics. Nat Biotech 2003, 21(3):262-267.

7. Dowling P, Meleady P, Dowd A, Henry M, Glynn S, Clynes M: Proteomic analysis of isolated membrane fractions from superinvasive cancer cells. Biochim Biophys Acta 2007, 1774(1):93-101.

8. Liang X, Zhao J, Hajivandi M, Wu R, Tao J, Amshey JW, Pope RM: Quantification of Membrane and Membrane-Bound Proteins in Normal and Malignant Breast Cancer Cells Isolated from the Same Patient with Primary Breast Carcinoma. J Proteome Res 2006, 5(10):2632-2641.

9. Stockwin LH, Blonder J, Bumke MA, Lucas DA, Chan KC, Conrads TP, Issaq HJ, Veenstra TD, Newton DL, Rybak SM: Proteomic Analysis of Plasma Membrane from Hypoxia-Adapted Malignant Melanoma. J Proteome Res 2006, 5(11):2996-3007.

10. Tan MH, Nowak NJ, Loor R, Ochi H, Sandberg AA, Lopez C, Pickren JW, Berjian R, Douglass HO Jr, Chu TM: Characterization of a new primary human pancreatic tumor line. Cancer Invest 1986, 4(1):15-23.

11. Tan M, Chu T: Characterization of the tumorigenic and metastatic properties of a human pancreatic tumor cell line (AsPC-1) implanted orthotopically into nude mice. Tumour Biol 1985, 6(1):89-98.

12. Deer EL, González-Hernández J, Coursen JD, Shea JE, Ngatia J, Scaife CL, Firpo MA, Mulvihill SJ: Phenotype and genotype of pancreatic cancer cell lines. Pancreas 2010, 39(4):425-35.

13. Nunomura K, Nagano K, Itagaki C, Taoka M, Okamura N, Yamauchi $Y$, Sugano S, Takahashi N, Izumi T, Isobe T: Cell surface labeling and mass spectrometry reveal diversity of cell surface markers and signaling molecules expressed in undifferentiated mouse embryonic stem cells. Mol Cell Proteomics 2005, 4(12):1968-1976.

14. Zhang L, Lun Y, Yan D, Yu L, Ma W, Du B, Zhu X: Proteomic analysis of macrophages: A new way to identify novel cell-surface antigens. J Immunol Methods 2007, 321(1-2):80-85.

15. Shi X, Friess H, Kleeff J, Ozawa F, Büchler MW: Pancreatic Cancer: Factors Regulating Tumor Development, Maintenance and Metastasis. Pancreatol 2001, 1(5):517-524

16. Keith B, Simon MC: Hypoxia-Inducible Factors, Stem Cells, and Cancer. Cell 2007, 129(3):465-472.

17. Nelson DA, Tan TT, Rabson AB, Anderson D, Degenhardt K, White E: Hypoxia and defective apoptosis drive genomic instability and tumorigenesis. Genes Dev 2004, 18(17):2095-2107.

18. Olson P, Hanahan D: Breaching the Cancer Fortress. Science 2009, 324(5933):1400-1401.

19. Kurahara H, Takao S, Maemura K, Shinchi H, Natsugoe S, Aikou T: Impact of Vascular Endothelial Growth Factor-C and -D Expression in Human Pancreatic Cancer. Clin Cancer Res 2004, 10(24):8413-8420.

20. Pàez-Ribes M, Allen E, Hudock J, Takeda T, Okuyama H, Viñals F, Inoue M, Bergers G, Hanahan D, Casanovas O: Antiangiogenic Therapy Elicits Malignant Progression of Tumors to Increased Local Invasion and Distant Metastasis. Cancer Cell 2009, 15(3):220-231. 
21. Büchler P, Reber HA, Lavey RS, Tomlinson J, Büchler MW, Friess $\mathrm{H}$, Hines OJ: Tumor hypoxia correlates with metastatic tumor growth of pancreatic cancer in an orthotopic murine model1. J Surg Res 2004, 120(2):295-303.

22. Walsh N, O'Donovan N, Kennedy S, Henry M, Meleady P, Clynes M, Dowling P: Identification of pancreatic cancer invasion-related proteins by proteomic analysis. Proteome Sci 2009, 7(1):3.

23. Cui Y, Wu J, Zong M, Song G, Jia Q, Jiang J, Han J: Proteomic profiling in pancreatic cancer with and without lymph node metastasis. Int I Cancer 2009, 124(7):1614-1621.

24. Roda O, Chiva C, Espuña G, Gabius HJ, Real FX, Navarro P, Andreu D: A proteomic approach to the identification of new tPA receptors in pancreatic cancer cells. Proteomics 2006, 6(S1):S36-S41.

25. Rathinam R, Alahari S: Important role of integrins in the cancer biology. Cancer Metastasis Rev 2010, 29(1):223-237.

26. Ryschich E, Khamidjanov A, Kerkadze V, Buchler MW, Zoller M, Schmidt J: Promotion of tumor cell migration by extracellular matrix proteins in human pancreatic cancer. Pancreas 2009, 38(7):804-810.

27. Fukushi Ji, Makagiansar IT, Stallcup WB: NG2 proteoglycan promotes endothelial cell motility and angiogenesis via engagement of galectin-3 and alpha 3 beta 1 Integrin. Mol Biol Cell 2004, 15(8):3580-3590.

28. Künzli B, Berberat P, Zhu Z, Martignoni M, Kleeff J, Tempia-Caliera A, Fukuda M, Zimmermann A, Friess H, Büchler M: Influences of the lysosomal associated membrane proteins (Lamp-1, Lamp-2) and Mac-2 binding protein (Mac-2-BP) on the prognosis of pancreatic carcinoma. Cancer 2002, 94(1):228-239.

29. Kobayashi S, Kishimoto T, Kamata S, Otsuka M, Miyazaki M, Ishikura H: Rapamycin, a specific inhibitor of the mammalian target of rapamycin, suppresses lymphangiogenesis and lymphatic metastasis. Cancer Sci 2007, 98(5):726-733.

30. Benmerah A, Scott M, Poupon V, Marullo S: Nuclear Functions for Plasma Membrane-Associated Proteins? Traffic 2003, 4(8):503-511.

31. Ludwig JA, Weinstein JN: Biomarkers in Cancer Staging, Prognosis and Treatment Selection. Nat Rev Cancer 2005, 5(11):845-856.

32. Harsha HC, Kandasamy K, Ranganathan P, Rani S, Ramabadran S, Gollapudi S, Balakrishnan L, Dwivedi SB, Telikicherla D, Selvan LD, Goel R, Mathivanan S, Marimuthu A, Kashyap M, Vizza RF, Mayer RJ, Decaprio JA, Srivastava S, Hanash SM, Hruban RH, Pandey A: A Compendium of Potential Biomarkers of Pancreatic Cancer. PLoS Med 2009, 6(4):e1000046.

33. Grote T, Logsdon CD: Progress on molecular markers of pancreatic cancer. Curr Opin Gastroenterol 2007, 23(5):508-514.

34. Guo X, Friess H, Graber HU, Kashiwagi M, Zimmermann A, Korc M: KAl1 expression is up-regulated in early pancreatic cancer and decreased in the presence of metastases. Cancer Res 1996, 56:4876-4880.

35. Gold DV, Modrak DE, Ying Z, Cardillo TM, Sharkey RM, Goldenberg DM: New MUC1 Serum Immunoassay Differentiates Pancreatic Cancer From Pancreatitis. J Clin Oncol 2006, 24(2):252-258.

36. Simeone DM, Ji B, Banerjee M, Arumugam T, Li D, Anderson MA, Bamberger AM, Greenson J, Brand RE, Ramachandran V, Logsdon CD: CEACAM1, a Novel Serum Biomarker for Pancreatic Cancer. Pancreas 2007, 34(4)

37. Almoguera C, Shibata D, Forrester K, Martin J, Arnheim N, Perucho M: Most human carcinomas of the exocrine pancreas contain mutant c-K-ras genes. Cell 1988, 53(4):549-554.

38. DiMagno E, Malagelada J, Moertel C, Go V: Prospective evaluation of the pancreatic secretion of immunoreactive carcinoembryonic antigen, enzyme, and bicarbonate in patients suspected of having pancreatic cancer. Gastroenterology 1977, 73(3):457-461.

39. Ritts RJ, Del Villano B, Go V, Herberman R, Klug T, Zurawski VJ: Initial clinical evaluation of an immunoradiometric assay for CA 19-9 using the NC serum bank. Int J Cancer 1984, 33(3):339-345.

40. Pignatelli $\mathrm{M}$, Durbin $\mathrm{H}$, Bodmer W: Carcinoembryonic antigen functions as an accessory adhesion molecule mediating colon epithelial cell-collagen interactions. Proc Natl Acad Sci USA 1990, 87(4):1541-1545.

doi:10.1186/1423-0127-17-74

Cite this article as: Liu et al: Membrane proteomic analysis of pancreatic cancer cells. Journal of Biomedical Science 2010 17:74.

\section{Submit your next manuscript to BioMed Central and take full advantage of:}

- Convenient online submission

- Thorough peer review

- No space constraints or color figure charges

- Immediate publication on acceptance

- Inclusion in PubMed, CAS, Scopus and Google Scholar

- Research which is freely available for redistribution 